\title{
Hyperglycemic Factor in Submandibular Glands and its Etiological Relations to Diabetes Mellitus in Mice
}

\author{
Yoon T. KIM, KaZumasa HOSHINO*, TSUNEKICHI HYODO**, \\ HENRY G. FRIESEN AND LINDA J. NAHYNYBIDA \\ Departments of Anatomy and Physiology, University of Manitoba, \\ Winnipeg, Manitoba, Canada R3E OW3 and Department of \\ Anatomy, Faculty of Medicine, Kyoto University, \\ Sakyo-ku, Kyoto 606, Japan
}

\begin{abstract}
Synopsis
Bilateral ligation of both the submandibular and parotid ducts of adult normal and mutant hyperinsulinemic diabetic mice resulted in a significant hypoglycemic effect. Therefore, we postulated that duct ligation may result in the removal of hyperglycemic factor (Hoshino et al., 1976) rather than a change in insulin sensitivity. Indeed, no change in specific binding of ${ }^{125}$ I-insulin was observed in membrane fractions from several tissues obtained from mice of either sex or strains before and after duct ligation. After slices of the submandibular gland were incubated for $4 \mathrm{hr}$ in Eagle's medium, an aliquot of the culture medium was injected i.p. into normal adult mice. A significant hyperglycemic effect was observed in $30 \mathrm{~min}$ in the injected animals. Eluates obtained by gel filtration of the crude extract of the submandibular gland were injected into normal adult mice, and hyperglycemia ensued. Thus, it is postulated that ligation of salivary ducts results in glandular atrophy and disappearance of the hyperglycemic factor which in turn leads to hypoglycemia and amelioration of diabetes mellitus, particularly of hyperinsulinemic type.
\end{abstract}

The salivary glands have been reported to play an important role in carbohydrate metabolism (Ogata, 1955) and in the secretion of a hyperglycemic substance (Hoshino et al., 1976). Experiments with bilateral duct-ligation or extirpation of the submandibular or parotid salivary glands revealed that salivary glands contain an insulin-inhibitor (Godlowski et al., 1971) and/or a substance causing hyperglycemia (Hiki et al., 1932; Hoshino, 1978). One

\footnotetext{
Received December 5, 1978.

* Present address: Department of Anatomy, Faculty of Medicine, Kyoto University, Sakyo-ku, Kyoto 606, Japan.

Requests for reprints should be sent to $\mathrm{K}$. H. at this address.

** Present address : Department of Medicine, Toho University School of Medicine, Ota-ku, Tokyo 143, Japan.
}

candidate for this role, extrapancreatic glucagon, has been identified in the submandibular gland (Silverman and Dunbar, 1974 ; Lawrence et al., 1976).

In addition to the hyperglycemic substance, the salivary glands also produce numerous factors, including nerve growth factor (Frazier et al., 1972) and epidermal growth factor (Savage et al., 1973). This evidence suggests that the salivary gland serves not only an exocrine function but also an endocrine function.

In diabetic patients, clinical improvement following surgical removal of submandibular glands has been claimed (Godlowski et al., 1971). Recently we reported that bilateral ligation of both the submandibular and parotid salivary ducts in mutant diabetic $\mathrm{C} 57 \mathrm{BL} / \mathrm{KsJ}-\mathrm{db} / \mathrm{db}$ mice significantly reduced the blood glucose level and body weight 
to the range found in non-diabetic controls (Hoshino et al., 1976).

The present study was undertaken to elucidate the mechanism by which bilateral ligation of the submandibular and parotid salivary ducts produces a lowering of blood glucose and the alleviation of diabetes mellitus in mice.

\section{Materials and Methods}

Two types of diabetic mice were used: (1) mutant diabetic C57BL/KsJ-db/db mice (hyperinsulinemic and insulin-insensitive) (Coleman and Hummel, 1967; 1969: Like and Chick, 1970; Wyse and Dulin, 1970) which are clinically comparable to maturity onset diabetes mellitus in man and (2) streptozotocininduced diabetic $\mathrm{C} 57 \mathrm{BL} / 6 \mathrm{~J}$ mice prepared by the method previously reported (Hoshino et al., 1976) (extremely hypoinsulinemic but insulin-sensitive) (Brosky, 1969; Junod et al., 1969; Rerup and Tardin, 1969) which are clinically comparable to juvenile non-obese diabetes mellitus. Non-diabetic litter mates of these mice were used as controls.

Blood glucose levels were determined by the ultraglucostat method (Hoshino et al., 1976). Plasma insulin levels were quantitated by the double antibody technique of Morgan and Lazarow (Morgan and Lazarow , 1963). To determine the insulin receptors, a binding assay of ${ }^{125} \mathrm{I}$-insulin to plasma membranes (Posner et al., 1974) was used.

The distribution of specific binding of ${ }^{125}$ I-insulin was studied in various tissues of normal non-diabetic male and female mice of four different strains namely, $\mathrm{C} 57 \mathrm{BL} / 6 \mathrm{~J}, \mathrm{CBA}, \mathrm{C} 3 \mathrm{H}$ and $\mathrm{BALB} / \mathrm{c}$ in preliminary experiments. Tissues used were submandibular gland, parotid gland, lung, kidney and liver. There appeared to be no strain or sex differences. Among the tissues tested, the highest binding of insulin was noted in the liver and next in the adipose tissue. Therefore, the liver was chosen as the model to study the effect of ligation of salivary ducts upon specific binding of insulin to plasma membrane.

Blood glucose levels were determined at $1,3,5$, $7,24,48$ and $72 \mathrm{hr}$ after $1 \mathrm{iu}$ of protamine-zinc insulin was injected into mice subcutaneously in order to investigate the sensitivity to exogenous insulin. The data were compared among mutant diabetic C57BL/KsJ-db-/db, streptozotocin-induced diabetic $\mathrm{C} 57 \mathrm{BL} / 6 \mathrm{~J}$, and non-diabetic C57BL/6J mice which had previously received surgical ligation of either the submandibular ducts or the parotid ducts, or both. A control group received only the sham operation.

In the in vitro experiments, the submandibular gland was excised from normal female C57BL/6J mice and immediately cut into slices. Sterile disposable Falcon tissue culture flasks (Catalog No. 3012) containing $500 \mathrm{mg}$ of tissue slices $(100 \mathrm{mg} / \mathrm{ml})$ in Eagle's medium were placed in a National incubator (Model 3212) at $37^{\circ} \mathrm{C}$ for $4 \mathrm{hr}$. The $\mathrm{pH}$ of the medium was approximately 7.4 with a gas mixture of $95 \% \mathrm{O}_{2}$ and $5 \% \mathrm{CO}_{2}$. At the end of the incubation, the medium was separated from the slices and centrifuged at $12,000 \times g$ for $30 \mathrm{~min}$. To test the effect of the substance(s) released from the submandibular tissue into the incubation medium, $0.1 \mathrm{~m} l$ of the supernatant was injected intraperitoneally into non-diabetic female C57BL/6J mice with or without ligation of the submandibular and parotid salivary ducts. The controls received Eagle's medium alone.

In an attempt to extract the hyperglycemic factor, submandibular glands from male and female nondiabetic normal CBA mice $(60$ and $300 \mathrm{mg}$ fresh weight, respectively) were homogenized in 10 volumes $(\mathrm{v} / \mathrm{w})$ of distilled water. After the homogenates were centrifuged twice at $12,500 \times g$ for $10 \mathrm{~min}$, the supernatant was lyophilized. All procedures were carried out at $4^{\circ} \mathrm{C}$ (Huang et al., 1977). The lyophilized crude extract $(10 \mathrm{mg} / \mathrm{ml}, \mathrm{w} / \mathrm{v})$ was then dissolved in distilled water or normal saline. The dissolved extract, $0.1 \mathrm{ml}$ of ${ }^{125} \mathrm{I}$-insulin as a marker $(10,000 \mathrm{cpm})$, and $0.1 \mathrm{ml}$ of Blue Dextran were applied to the Sephadex G-100 column $(0.8 \times 40 \mathrm{~cm})$ equilibriated, and eluted with distilled water. The eluates were collected with a Buchler fraction collector at a flow rate of $9.4 \mathrm{ml}$ per hour at $4^{\circ} \mathrm{C}$. The absorbance of each fraction was read at $280 \mathrm{~nm}$ using a UNICAM SP-1800 ultraviolet spectrophotometer. The radioactivity of ${ }^{125}$ I-insulin was determined using a Packard Auto Gamma Scintillation Spectrophotometer (Model 3002). Eluates were lyophilized and subsequently redissolved in normal saline and bioassayed for the hyperglycemic factor in the same manner as was used for assaying the incubation medium.

\section{Results}

Bilateral ligation of the submandibular and parotid ducts for one week resulted in a significant reduction in the blood glucose level and specific binding of insulin to plasma membrane in both streptozotocininduced diabetic and non-diabetic C57BL/6J control mice. However, the plasma insulin levels were not altered by salivary duct ligation (Table 1). Likewise, in mutant diabetic $\mathrm{C} 57 \mathrm{BL} / \mathrm{KsJ}-\mathrm{db} / \mathrm{db}$ and non-diabetic litter mate controls, blood glucose levels and body weights were significantly de- 
creased. However, the specific binding of insulin to hepatic plasma membranes were unchanged. Furthermore, plasma insulin levels in the mutant diabetic mice were significantly lowered (Table 2).

The influence of exogenous insulin upon the blood glucose levels in experimental animals is summarized in Figs. 1 and 2 . The blood glucose levels dropped sharply $1 \mathrm{hr}$ after injection and returned to the preinjection levels in $24 \mathrm{hr}$ in streptozotocininduced diabetic mice and in $72 \mathrm{hr}$ in mutant diabetic mice. Changes in the blood glucose levels of mutant diabetic mice with bilateral duct ligation of the submandibular and parotid glands closely paralleled that of the non-diabetic control group.

The changes in blood glucose levels in mice injected intraperitoneally with an aliquot of salivary gland incubation medium were shown in Table 3. A significant elevation of blood glucose occurred at 30 min.

Table 1. Influence of salivary duct ligation upon body weight, blood glucose, insulin receptor, and plasma insulin in non-diabetic and streptozotocin-induced $\mathrm{C} 57 \mathrm{BL} / 6 \mathrm{~J}$ mice (Prior to ligation versus 1 week after ligation)

\begin{tabular}{llcc}
\hline \multicolumn{1}{c}{ Parameters } & & $\begin{array}{c}\text { Non-diabetic } \\
\text { C57BL/6J mice }\end{array}$ & $\begin{array}{c}\text { Streptozotocin-induced } \\
\text { C57BL/6J mice }\end{array}$ \\
\hline Body weight $(\mathrm{g})$ & Before & $23.3 \pm 0.4^{*}(6)(\mathbf{P}<.05)$ & $21.0 \pm 1.1(4)(\mathrm{N} . \mathrm{S})$. \\
& After & $16.6 \pm 0.4(6)$ & $18.1 \pm 1.7(6)$ \\
Blood glucose level $(\mathrm{mg} \%)$ & Before & $115.1 \pm 5.7(15)(\mathrm{P}<.05)$ & $249.2 \pm 10.7(12)(\mathrm{P}<.05)$ \\
Specific binding of ${ }^{125} \mathrm{I}$-insulin & After & $64.2 \pm 7.7(6)$ & $153.8 \pm 31.7(6)$ \\
to liver plasma membrane $(\%)$ & Before & $17.5 \pm 0.9(5)(\mathbf{P}<.05)$ & $15.1 \pm 0.5(5)(\mathrm{P}<.05)$ \\
Plasma insulin $(\mu \mathrm{U} / l)$ & After & $13.6 \pm 0.6(6)$ & $11.4 \pm 0.4(4)$ \\
& Before & $12(5)^{* *}$ & $<12(5)$ \\
& After & $12(5)$ & $<12(5)$ \\
\hline
\end{tabular}

( ) Number of animals.

* Mean \pm S.E.

()$^{* *}$ Number of animals pooled.

Table 2. Influence of salivary duct ligation upon body weight, blood glucose, insulin receptor, and plasma insulin in non-diabetic and mutant diabetic C57BL/KsJ mice (Prior to ligation versus 1 week after ligation)

\begin{tabular}{|c|c|c|c|}
\hline Parameters & & $\begin{array}{c}\text { Non-diabetic } \\
\text { C57BL/KsJ mice }\end{array}$ & $\begin{array}{c}\text { Mutant diabetic } \\
\text { C57BL/KsJ-db/db mice }\end{array}$ \\
\hline \multirow[b]{2}{*}{ Body weight (g) } & Before & $24.8 \pm 0.4^{*}(6)$ & $46.4 \pm 2.5(9)$ \\
\hline & After & $17.7 \pm 0.2(6)^{(P<.05)}$ & $38.1 \pm 1.5(9)$ (N.S.) \\
\hline \multirow{2}{*}{ Blood glucose level (mg\%) } & Before & $139.9 \pm 10.3 \quad(9) \quad(P<.05)$ & $300.6 \pm 17.6(11) \quad(P<.05)$ \\
\hline & After & $68.5 \pm 5.8(6)(1<.00)$ & $63.9 \pm 5.2(5)$ \\
\hline \multirow{2}{*}{$\begin{array}{l}\text { Specific binding of } 125 \text { I-insulin } \\
\text { to liver plasma membrane }(\%)\end{array}$} & Before & $14.2 \pm 0.7(5)$ & $10.9 \pm 1.8(6)$ (NS) \\
\hline & After & $15.6 \pm 0.1$ (5) (N.S.) & $10.1 \pm 0.6(5)$ (N.S.) \\
\hline \multirow{2}{*}{ Plasma insulin $(\mu \mathrm{U} / \mathrm{cc})$} & Before & $16(18)^{* *}$ & $117(7)$ \\
\hline & After & $12(6)$ & $13(6)$ \\
\hline
\end{tabular}

\footnotetext{
( ) Number of animals.

* Mean \pm S.E.

( )** Number of animals pooled.
} 


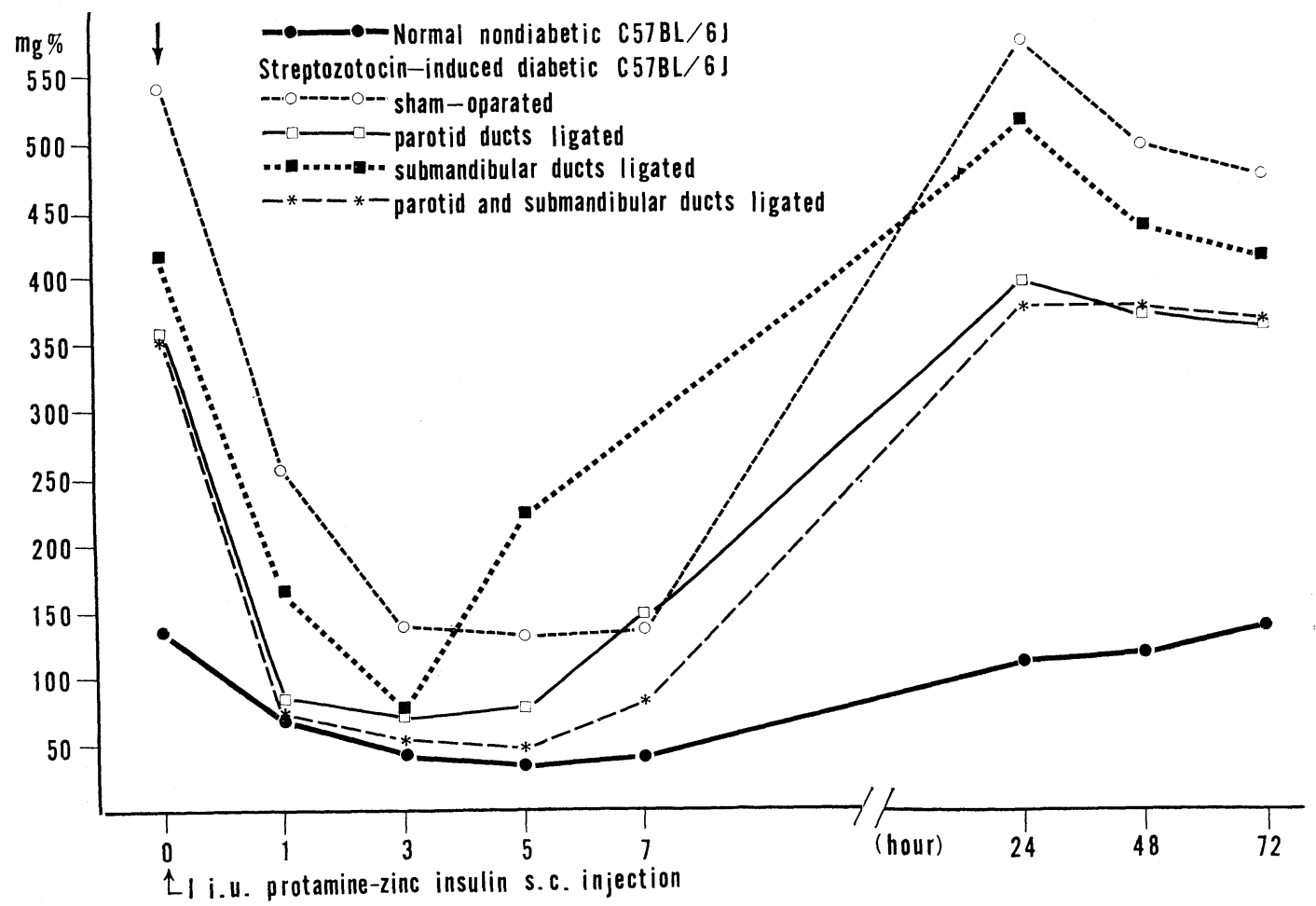

Fig. 1. Changes in blood glucose levels in streptozotocin-induced diabetic mice after single dorsal subcutaneous injection with 1 i.u. of protamine-zinc insulin.

Table 3. Hyperglycemic effects of i.p. injection of Eagle's medium incubated with slices of normal mouse submandibular gland for $4 \mathrm{hr}$

\begin{tabular}{|c|c|c|c|c|c|c|}
\hline \multirow{3}{*}{$\begin{array}{l}\text { Time } \\
(\min .)\end{array}$} & \multicolumn{6}{|c|}{ Non-diabetic C57BL/6J female mice } \\
\hline & \multicolumn{2}{|c|}{ Control (5) } & \multicolumn{2}{|c|}{ Non-ligated (7) } & \multicolumn{2}{|c|}{ Ligated (7) } \\
\hline & $\begin{array}{l}\text { Blood glucose } \\
\text { level (mg\%) }\end{array}$ & $\begin{array}{c}\%^{*} \\
\text { change }\end{array}$ & $\begin{array}{l}\text { Blood glucose } \\
\text { level (mg\%) }\end{array}$ & $\begin{array}{c}\% \\
\text { change }\end{array}$ & $\begin{array}{l}\text { Blood glucose } \\
\text { level (mg } \%)\end{array}$ & $\begin{array}{c}\% \\
\text { change }\end{array}$ \\
\hline 0 & $102.8 \pm 7.2^{* *}$ & 0 & $101.7 \pm 5.9$ & 0 & $81.1 \pm 49.9$ & 0 \\
\hline 15 & $111.1 \pm 6.8$ & +8.1 & & - & - & {[} \\
\hline 30 & $106.1 \pm 5.9$ & +3.2 & $139.1 \pm 5.1$ & $+36.8(\mathrm{P}<.01)$ & $102.3 \pm 4.4$ & $+26.1(\mathrm{P}<.05)$ \\
\hline 60 & $104.4 \pm 5.6$ & +1.6 & $122.6 \pm 5.1$ & $+20.6(\mathrm{P}<.05)$ & $88.7 \pm 4.1$ & +9.4 \\
\hline 90 & $105.1 \pm 6,1$ & +2.2 & $93.9 \pm 6.4$ & -7.7 & $64.6 \pm 9.4$ & -20.3 \\
\hline 120 & $100.9 \pm 2.3$ & -1.8 & $74.1 \pm 6.3$ & $-27.1(\mathrm{P}<.05)$ & $54.7 \pm 8.0$ & $-32.6(\mathrm{P}<.05)$ \\
\hline
\end{tabular}

( ) Number of animals.

* \% change over preinjection level.

** Mean \pm S.E. 
Gel filtration of crude extracts of the submandibular gland exhibited three distinct peaks. The first peak (Peak 1) was eluted before ${ }^{125} 1$-insulin marker (Fig. 3). Similar elution patterns were obtained from crude extracts prepared from male and female mice (data not shown). A single aqueous intraperitoneal injection containing lyophilized eluate from Peak 1 into $\mathrm{C} 57 \mathrm{BL} / 6 \mathrm{~J}$ female test mice significantly elevated blood glucose levels in $30 \mathrm{~min}$ (Table 4).

When non-diabetic female C57BL/6J mice underwent bilateral ligation of the submandibular and parotid salivary ducts,

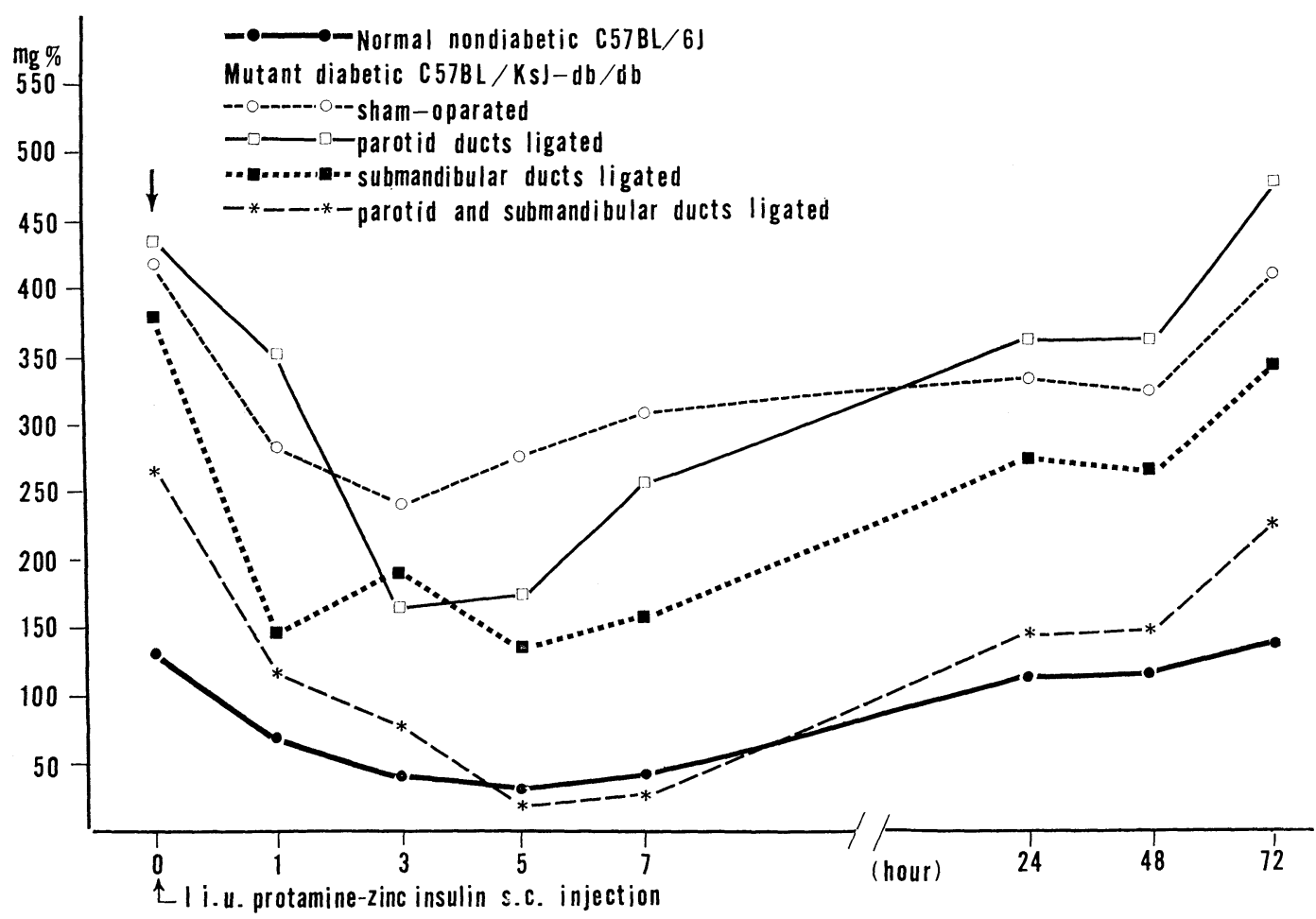

Fig. 2. Changes in blood glucose levels in mutant diabetic mice after single dorsal subcutaneous injections with 1 i.u. of protamine-zinc insulin.

Table 4. Hyperglycemic effects of extracts from Peak-1 separated on Sephadex G-100

\begin{tabular}{|c|c|c|c|c|c|c|}
\hline \multirow{2}{*}{$\begin{array}{l}\text { Time } \\
\text { (min.) }\end{array}$} & \multicolumn{2}{|c|}{$\begin{array}{c}\text { Cotrol (Physiological } \\
\text { saline) (5) }\end{array}$} & \multicolumn{2}{|c|}{$\begin{array}{l}\text { Extract from female } \\
\text { CBA mice }(2)\end{array}$} & \multicolumn{2}{|c|}{$\begin{array}{l}\text { Extract from male } \\
\text { CBA mice }(3)\end{array}$} \\
\hline & $\begin{array}{l}\text { Blood glucose } \\
\text { level (mg\%) }\end{array}$ & $\begin{array}{c}\%{ }^{*} \\
\text { change }\end{array}$ & $\begin{array}{l}\text { Blood glucose } \\
\text { level (mg\%) }\end{array}$ & $\begin{array}{c}\% \\
\text { change }\end{array}$ & $\begin{array}{l}\text { Blood glucose } \\
\text { level (mg\%) }\end{array}$ & $\begin{array}{c}\% \\
\text { change }\end{array}$ \\
\hline 0 & $102.8 \pm 7.2^{* *}$ & 0 & $55.5 \pm 5.5$ & 0 & $45.0 \pm 1.2$ & 0 \\
\hline 15 & $111.1 \pm 6.8$ & +8.1 & $104.5 \pm 14.5$ & $+88.3(\mathbf{P}<.01)$ & $76.3 \pm 5.5$ & $+69.6(\mathrm{P}<.01)$ \\
\hline 30 & $106.1 \pm 5.9$ & +3.2 & $125.0 \pm 7.0$ & $+125.2(\mathrm{P}<.01)$ & $88.3 \pm 9.8$ & $+96.2(\mathrm{P}<.01)$ \\
\hline 60 & $104.4 \pm 5.6$ & +1.6 & $92.0 \pm 17.0$ & $+65.8(\mathrm{P}<.05)$ & $64.7 \pm 7.3$ & $+43.8(\mathrm{P}<.05)$ \\
\hline 90 & $105.1 \pm 6.1$ & +2.2 & $84.5 \pm 21.5$ & $+52.3(\mathrm{P}<.05)$ & $61.0 \pm 4.2$ & $+35.6(\mathrm{P}<.05)$ \\
\hline 120 & $100.9 \pm 2.3$ & -1.8 & $76.0 \pm 4.0$ & $+36.9(\mathrm{P}<.05)$ & $38.0 \pm 1.5$ & -15.6 \\
\hline
\end{tabular}

( ) Number of animals.

* \% change over preinjection level.

** Mean \pm S.E. 
blood glucose levels but not body weights were reduced significantly.

\section{Discussion}

Bilateral ligation of the salivary ducts was found to elicit a hypoglycemic effect (Hoshino et al., 1976), but its mode of action was unknown. To elucidate possible mechanisms a systematic analysis was attempted. Initially the variation in insulin receptors was assessed via the specific binding of ${ }^{125} 1$-insulin to plasma membrane preparations obtained from various tissues, because no data has been reported concerning the distribution of insulin receptors in mice. The specific binding was highest in the liver. It coincided with the previous observations made among various tissues in guinea pig, pigeon, rabbit, monkey, sheep and rat (Posner et al., 1974). The liver is a major site of insulin action and degradation (LeCam et al., 1975). In the present study, specific binding to the submandibular gland plasma membrane was rather low. Therefore, the liver plasma membrane was used for subsequent experiments but no direct relation between binding and the alleviation of diabetes mellitus by the ligation of salivary ducts was noted. Contrasting but interesting results were observed one week following bilateral ligation of the submandibular and parotid ducts between streptozotocin-induced diabetic and mutant diabetic mice as follows: although both blood glucose levels and body weight were significantly reduced in both diabetic groups, plasma insulin levels were significantly reduced in only the mutant diabetic mice. However, the specific binding of ${ }^{125} 1$-insulin to liver plasma membrane was significantly

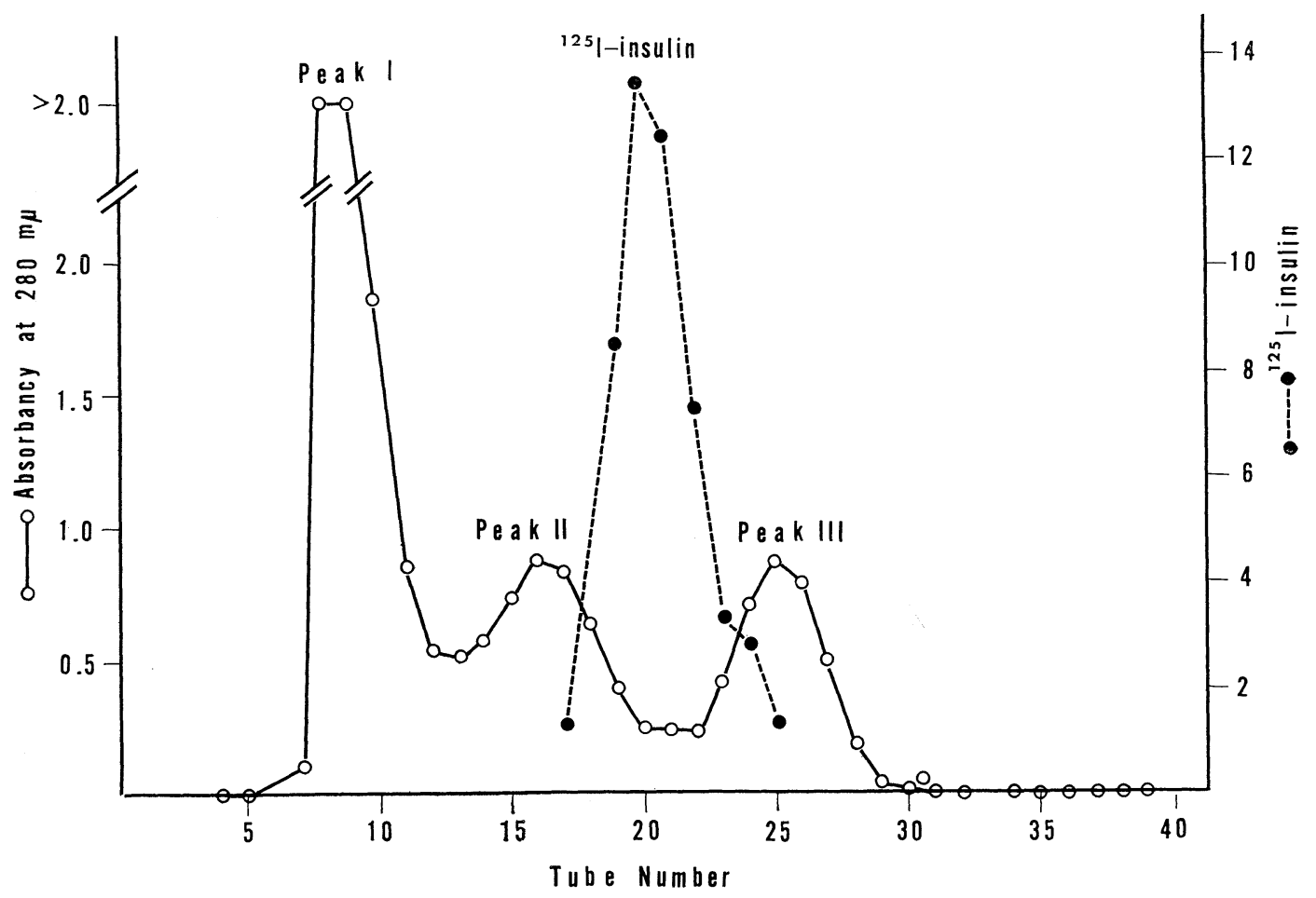

Fig. 3. Gel filtration of extracts of mouse submandibular glands on Sephadex G-100. 
reduced after ductal ligation in streptozotocin-induced diabetic mice but not in mutant diabetics.

Because streptozotocin-induced diabetic and non-diabetic control mice were supposed to be peripherally sensitive to exogenous insulin, it was not surprising to find the rapid hypoglycemic responses to $1 \mathrm{iu}$ of protamine-zinc insulin administered exogenously in these mice. However, in all groups of streptozotocin-induced diabetic mice, the blood glucose levels returned to the preinjection level in $24 \mathrm{hr}$. After injection of exogenous insulin in mutant mice, blood glucose levels were reduced most evidently in those with bilateral ligation of the submandibular and parotid ducts and the reduced level remained within the preinjection level for some time. Bilateral ligation of either the submandibular or parotid ducts alone, or sham operation caused lesser degrees of reduction in blood glucose levels in mutant diabetics than in streptozotocin-induced mice. In contrast to streptozotocin-induced diabetic mice, mutant diabetic mice were hyperinsulinemic and much less sensitive to exogenous insulin when both the submandibular and parotid ducts were not ligated. It was reported previously that treatment with protaminezinc insulin up to 100 units per $100 \mathrm{~g}$ body weight in $\mathrm{db}-\mathrm{db}$ diabetic mice having blood glucose levels of $500 \mathrm{mg} / 100 \mathrm{ml}$ or higher fail to reduce the blood glucose concentration to normal levels (Coleman and Hummel, 1969). Following ligation of both the submandibular and parotid ducts, not only the blood glucose levels and body weight (Hoshino et al., 1976) but also the plasma insulin level dropped to non-diabetic levels (Table 1). When the exogenous insulin was administered, these operated mutant diabetic mice became sensitive to it in a manner similar to that shown by non-diabetic control mice (Fig. 2).

We postulated previously (Hoshino et al., 1976) that the ligation of the submandibular duct may result in cessation of the production and thus elimination of a hyperglycemic factor in the submandibular gland followed by the alleviation of hyperinsulinemia, hyperglycemia, and insulinresistance in mutant diabetic mice. This postulation was partially supported by the recent report that bilateral ligation of both the submandibular and parotid ducts caused a significant reduction in blood glucose levels only $18 \mathrm{hr}$ following the operation in normal male C57BL/6J mice and their reduced levels remained low until the end of the experiments at 7 days. During the same experiments, histological features of the salivary glands revealed the cessation of their secretory functions. These glands with their ducts ligated underwent gradual, but steady, changes of degeneration and became much smaller and atrophic. At $164 \mathrm{hr}$ after ligation, both the parotid and submandibular glands showed marked atrophic features which were indistinguishable from each other (Hoshino, 1978). These data strongly suggest that the restriction of food intake caused by the salivary duct ligation cannot be considered as a major cause of hypoglycemic effects induced by duct ligation.

Coleman and Hummel (1969) observed that $\mathrm{db}-\mathrm{db}$ diabetic mice, 6 to 12 weeks of age, normally consume food 6 to $7 \mathrm{~g}$. per day. During three months of restricted feeding ( $1 \mathrm{~g}$ of food per day) their blood glucose concentrations measured just before feeding (fasted blood) decreased slightly but remained distinctly higher than that observed in fasted normal mice. They also stated that the increased activities of the insulin-dependent enzymes, and the degranulation of $\beta$-cells of the islets of Langerhans are quite consistent with the increased levels of circulating insulin observed in younger $\mathrm{db}-\mathrm{db}$ diabetic mice. They could not, however, explain the reason for the failure of these increased amounts of 
insulin to regulate effectively blood glucose concentration (Coleman and Hummel, 1969). In the present study, the bilateral duct ligation of the both salivary glands of $\mathrm{db}-\mathrm{db}$ diabetic mice reduced remarkably circulating levels of increased amounts of insulin as well as glucose levels to normal levels in a week after the operation. On the other hand, from our laboratory, it was previously reported that body weights and blood glucose levels of streptozotocin-induced diabetic mice were not changed from the preoperative levels when they were determined three weeks after the bilateral ligation of the submandibular and parotid ducts (Hoshino et al., 1976). Therefore, it again seems very difficult to attribute our results of a significant reduction of circulating and blood glucose levels following the salivary duct ligation simply to food intake restriction due to xerostomia as a causative factor.

It may now be postulated that excess extrapancreatic hyperglycemic factor in the submandibular gland stimulated the overproduction of insulin to make mutant diabetic mice hyperinsulinemic and peripherally insulin-resistant. Following elimination of the extrapancreatic hyperglycemic factor by minor surgery, it was not necessary to overproduce insulin in order to counteract the hyperglycemia, thus every symptom disappeared; thus, it is easy to accept the fact that an impairment of the insulin receptor system need not be postulated.

\section{References}

Brosky, G. (1969). Diabetes 18, 606.

Coleman, D. L. and K. P. Hummel (1967). Diabetologia 3, 238.

Coleman, D. L. and K. P. Hummel. Proceeding of the Sixth Congress of the International Diabetes Foundation (edited by J. Ostman). Excerpta Medica Foundation, Amsterdam, p. 813 (1969).

Frazier, W. A., R. H. Angeletti and R. H. Bradshaw (1972). Science 176, 482.

Godlowski, Z. Z., M. Gazda and B. T. Wither (1971). Laryngoscope 18, 1337.

Hiki, Y., K. Akazawa, T. Bann, Y. Miyazaki and N. Takizawa (1932). Tr. Jap. Path. Soc. 22, 273.

Hoshino, K. (1978). Acta Anat. Nippon. 53, 107. (In Japanese)

Hoshino, K., R. F. Decker, F. Molnar and Y. T. Kim (1976). Arch. Oral Biol. 21, 105.

Huang, J. C.-C., K. Hoshino, Y. T. Kim and F. S. Chebib (1977). Canad. J. Physiol. and Pharm. 55, 1107.

Junod, A., A. E. Lambert, W. Stauffacher and A. E. Renold (1969). J. Clin. Invest. 48, 2129.

Lawrence, A. M., S. Tan, S. Hojvat, L. Kirsteins and J. Mitton (1967). Metabolism 25, 1405.

LeCam, A., P. Freychet and P. Lenoir (1975). Diabetes 24, 566 .

Like, A. A. and W. L. Chick (1970). Diabetologia 6, 207.

Morgan, C. R. and A. A. Lazarow (1963). Diabetes 12,115 .

Ogata, T. (1955). Endocrinol. Jap. 2, 2474.

Posner, B. I., P. A. Kelly, R. P. C. Shiu and H. G. Friesen (1974). Endocrinology 96, 521.

Rerup, C. and F. Tarding (1969). Europ. J. Pharm. $7,89$.

Savage, C. R., J. H. Hash and S. Cohen (1973). J. Biol. Chem. 248, 7669.

Silverman, H. and J. C. Dunbar (1974). Bull. Sinai Hosp. Detroit 22, 192.

Wyse, B. M. and W. E. Dulin (1970). Diabetologia 6, 268. 